\title{
Overnight loss of pigmented hair in autoimmune autonomic neuropathy treated with IVIg
}

Lindsey E. Turner, Sean J. Pittock, MD, Marian T. McEvoy, MD, and Eoin P. Flanagan, MBBCh

Neurol Neuroimmunol Neuroinflamm 2019;6:e620. doi:10.1212/NXI.0000000000000620
Correspondence

Dr. Flanagan

Flanagan.eoin@mayo.edu

Autoimmune autonomic neuropathy is an immune-mediated disease, which can be associated with high titers of pathogenic antibodies to the nicotinic ganglionic acetylcholine receptor (gAChR). ${ }^{1-3}$ IV immunoglobulin (IVIg) is a commonly used treatment in autoimmune autonomic neuropathy associated with gAChR antibodies. Herein, we report a patient with an autonomic neuropathy associated with high-titer gAChR antibodies who developed selective pigmented hair loss while being treated with IVIg.

\section{Methods}

\section{Standard protocol approvals, registrations, and patient consents}

The patient consented to the use of their medical records and image for this publication.

\section{Case report}

A 34-year-old man with well-controlled type 1 diabetes (treated with an insulin pump), ulcerative colitis previously treated with colectomy, thyroiditis, and previous cerebellitis presented with the subacute onset of a severe pandysautonomia. Following an infectious illness, over the course of a few weeks, he developed light-headedness on standing, recurrent syncope, early satiety, bloating, difficulties emptying his bladder, erectile dysfunction, visual disturbance when transitioning from dark to light, dry eyes, and dry mouth. He received symptomatic treatment with oral fludrocortisone ( $0.1 \mathrm{mg}$ twice daily) and midodrine ( $10 \mathrm{mg} 3$ times per day) and increased his fluid intake. He continued to have syncopal episodes weekly and was unable to ambulate due to symptomatic orthostasis requiring him to use a scooter. He had a pacemaker placed for bradycardia episodes. At the time of referral to our facility, 1 year after onset, his neurologic examination revealed a lying blood pressure of $145 / 102$ with a pulse of 69 that dropped to $71 / 42$ with a pulse of 72 . His pupils were dilated and unreactive to light. Pinprick and vibration sensation were normal. He had stable mild ataxia as a residua of his previous cerebellitis. The remainder of the neurologic examination was normal. Autonomic testing revealed marked cardiovagal, cardiovascular adrenergic, and sudomotor abnormalities; a thermoregulatory sweat test showed global anhidrosis (figure $1 \mathrm{~A}$ ). His serum gAChR antibodies were noted to be markedly elevated (titer, $1.47 \mathrm{nmol} / \mathrm{L}$; normal, $\leq 0.02$ ). He was diagnosed with an autoimmune autonomic neuropathy associated with gAChR antibodies; he also had mildly elevated glutamic acid decarboxylase 65 (titer, $0.43 \mathrm{nmol} / \mathrm{L}$ ) and insulin (titer, $0.33 \mathrm{nmol} / \mathrm{L}$ ) autoantibodies (normal range, $0-0.02 \mathrm{nmol} / \mathrm{L}$ ) consistent with his history of autoimmune type 1 diabetes. He received $0.4 \mathrm{~g} / \mathrm{kg}$ of IVIg once daily for 3 days, followed by once weekly for 6 weeks and every other week for 6 weeks. He had mixed white and black hair (figure 2A), and after beginning his initial IVIg infusion, all dark hair fell out over 24-48 hours (figure 2B). Diffuse alopecia areata (AA) was diagnosed. He reported a moderate improvement in his autonomic symptoms with IVIg and thus decided to continue IVIg, despite the dark hair loss coinciding with its use. Oral

From the Undergraduate Research Employment Program (L.E.T.), Neuroimmunology, Mayo Clinic; Department of Neurology (S.J.P., E.P.F.), Department of Laboratory Medicine and Pathology (S.J.P., E.P.F.), and Department of Dermatology (M.T.M.), Mayo Clinic, Rochester, MN.

Go to Neurology.org/NN for full disclosures. Funding information is provided at the end of the article.

The Article Processing Charge was funded by the authors.

This is an open access article distributed under the terms of the Creative Commons Attribution-NonCommercial-NoDerivatives License 4.0 (CC BY-NC-ND), which permits downloading and sharing the work provided it is properly cited. The work cannot be changed in any way or used commercially without permission from the journal. 
Figure 1 Thermoregulatory sweat test before and after treatment

A
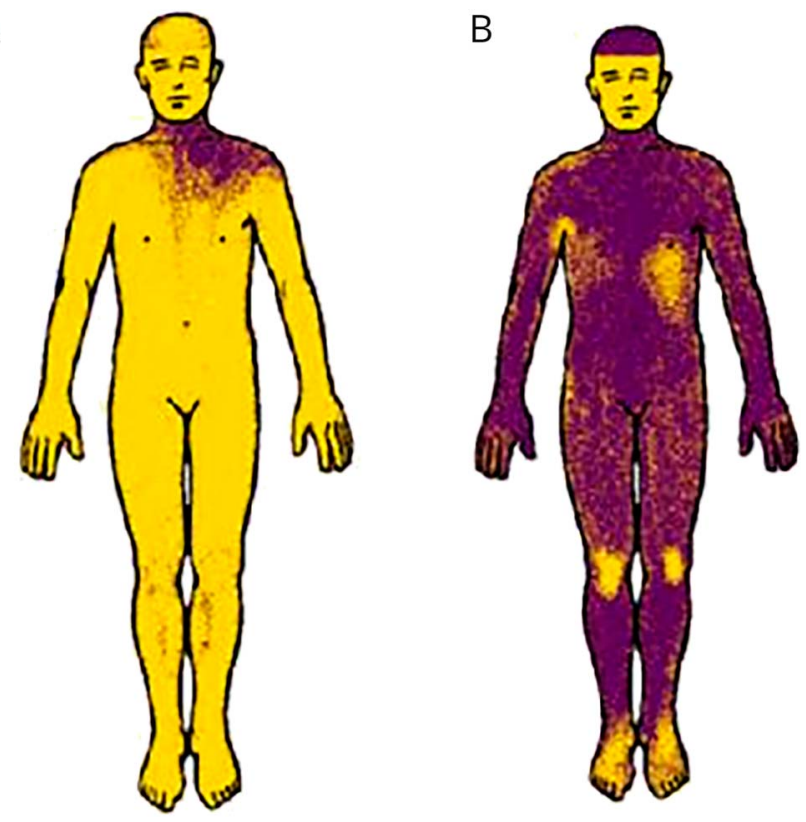

Thermoregulatory sweat test shows global anhidrosis (yellow) before IV immunoglobulin (IVIg) (A) with marked improvement (purple = normal sweating) after IVIg and pyridostigmine treatment (B).

mycophenolate ( $1,000 \mathrm{mg}$ twice daily) and pyridostigmine (60 mg 3 times daily) were added, and 1 year after initial assessment, autonomic testing and a repeat sweat test showed improvement (figure 1B). He was transitioned to rituximab due to difficulty achieving therapeutic mycophenolate levels in the setting of his ileostomy. He remained without dark hair 5 years later.

\section{Discussion}

This case was characteristic of an autoimmune autonomic neuropathy associated with high-titer gAChR antibodies. ${ }^{3}$ The rapid development of autonomic failure in the setting of well-controlled diabetes treated with an insulin pump, hightiter gAChR antibodies, and response to IVIg all suggested a primary diagnosis of an autoimmune autonomic neuropathy associated with gAChR antibodies, rather than a diabetic autonomic neuropathy. ${ }^{3}$ Strikingly, coinciding with his IVIg treatment, he developed acute selective dark hair loss (figure 2) essentially turning his hair white overnight.

Historically, this syndrome of sudden whitening of hair has been termed "Marie Antoinette syndrome" after the hair of the Queen of France suddenly turned white when sentenced to execution during the French revolution. ${ }^{4}$ The pathogenesis of sudden whitening of hair is unknown, but diffuse AA has been proposed as the likely etiology given white hair lack follicular melanocytes, a suspected immune target in AA, potentially explaining selective dark hair loss. ${ }^{5,6}$ An IVIg adverse effect was suspected given the temporal relationship and rare reports of alopecia with IVIg, ${ }^{7}$ although AA unrelated to IVIg was possible; our case was limited by absence of a scalp biopsy to assess for immunoglobulin deposition. The stress of the infusion and his autoimmune predisposition were other potential contributors to this intriguing phenomenon. ${ }^{6}$

\section{Study funding}

No targeted funding reported.

\section{Disclosure}

L.E. Turner reports no disclosures. S.J. Pittock is a named inventor on patents (\#12/678,350 filed 2010 and \#12/

Figure 2 Selective dark hair loss
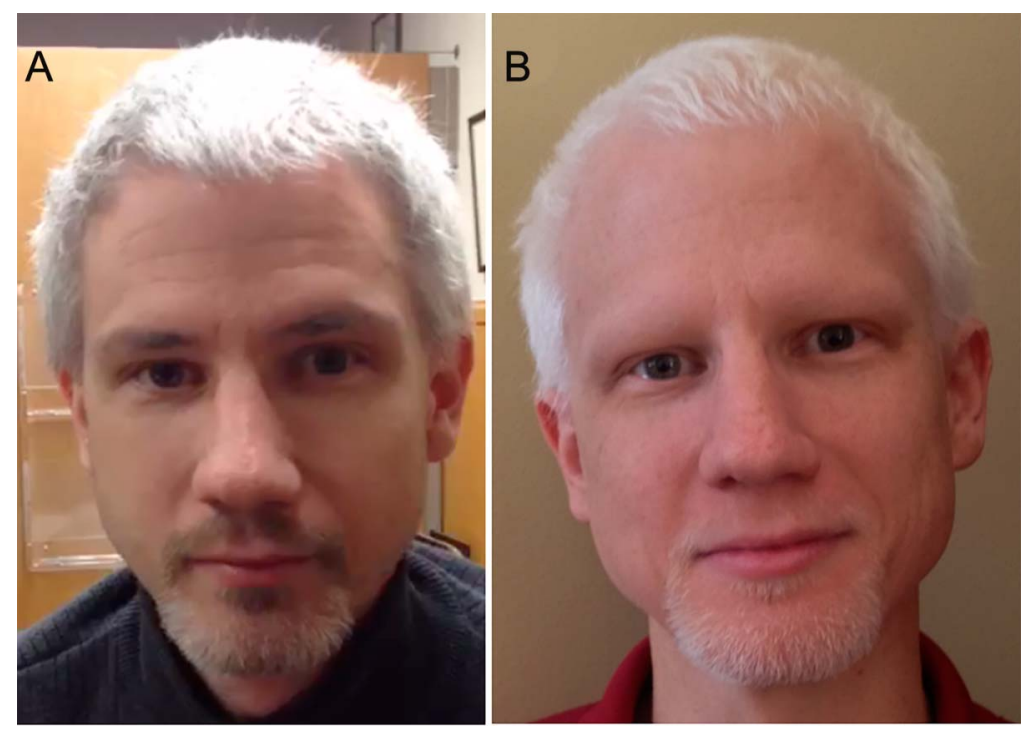

The patient before $(A)$ and after IV immunoglobulin treatment (B). 
573,942 filed 2008) that relate to functional AQP4/NMOIgG assays and NMO-IgG as a cancer marker; receives research support from Alexion Pharmaceuticals, Inc., the Guthy-Jackson Charitable Foundation, and the NIH (NS065829). S.J. Pittock has provided consultation to Alexion Pharmaceuticals, MedImmune LLC, and Chugai Pharma but has received no personal fees or personal compensation for these consulting activities. All compensation for consulting activities is paid directly to Mayo Clinic. M.T. McEvoy reports no disclosures. E.P. Flanagan is a site principal investigator in a randomized placebo-controlled clinical trial of inebilizumab (A CD19 inhibitor) in neuromyelitis optica spectrum disorders funded by MedImmune/Viela Bio. He receives no personal compensation and just receives reimbursement for the research activities related to the trial. Go to Neurology. org/NN for full disclosures.

\section{Publication history}

Received by Neurology: Neuroimmunology \& Neuroinflammation July 11, 2019. Accepted in final form August 9, 2019.

\section{Appendix Authors}

\begin{tabular}{llll}
\hline Name & Location & Role & Contribution \\
\hline $\begin{array}{l}\text { Lindsey E. } \\
\text { Turner }\end{array}$ & $\begin{array}{l}\text { Mayo Clinic, } \\
\text { Rochester, } \\
\text { MN }\end{array}$ & Author & $\begin{array}{l}\text { Drafted the manuscript; analyzed } \\
\text { and interpreted the data; and } \\
\text { helped compose the figure }\end{array}$ \\
\hline
\end{tabular}

Appendix (continued)

\begin{tabular}{|c|c|c|c|}
\hline Name & Location & Role & Contribution \\
\hline $\begin{array}{l}\text { Sean J. } \\
\text { Pittock, } \\
\text { MD }\end{array}$ & $\begin{array}{l}\text { Mayo Clinic, } \\
\text { Rochester, } \\
\text { MN }\end{array}$ & Author & $\begin{array}{l}\text { Interpreted the data and revised } \\
\text { the manuscript for intellectual } \\
\text { content }\end{array}$ \\
\hline $\begin{array}{l}\text { Marian T. } \\
\text { McEvoy, } \\
\text { MD }\end{array}$ & $\begin{array}{l}\text { Mayo Clinic, } \\
\text { Rochester, } \\
\text { MN }\end{array}$ & Author & $\begin{array}{l}\text { Interpreted the data and revised } \\
\text { the manuscript for intellectual } \\
\text { content }\end{array}$ \\
\hline $\begin{array}{l}\text { Eoin P. } \\
\text { Flanagan, } \\
\text { MBBCh }\end{array}$ & $\begin{array}{l}\text { Mayo Clinic, } \\
\text { Rochester, } \\
\text { MN }\end{array}$ & Author & $\begin{array}{l}\text { Designed and conceptualized the } \\
\text { study; analyzed and interpreted } \\
\text { the data; helped compose the } \\
\text { figure; revised the manuscript for } \\
\text { intellectual content; and study } \\
\text { supervision }\end{array}$ \\
\hline
\end{tabular}

\section{References}

1. Lennon VA, Ermilov LG, Szurszewski JH, Vernino S. Immunization with neuronal nicotinic acetylcholine receptor induces neurological autoimmune disease. J Clin Invest 2003;111:907-913.

2. Vernino S, Ermilov LG, Sha L, Szurszewski JH, Low PA, Lennon VA. Passive transfer of autoimmune autonomic neuropathy to mice. J Neurosci 2004;24:7037-7042.

3. Vernino S, Low PA, Fealey RD, Stewart JD, Farrugia G, Lennon VA. Autoantibodies to ganglionic acetylcholine receptors in autoimmune autonomic neuropathies. $\mathrm{N} \mathrm{Engl}$ J Med 2000;343:847-855.

4. Navarini AA, Nobbe S, Trüeb RM. Marie Antoinette syndrome. Arch Dermatol 2009; 145:656.

5. Tobin DJ, Paus R. Graying: gerontobiology of the hair follicle pigmentary unit. Exp Gerontol 2001;36:29-54.

6. Skellett AM, Millington GW, Levell NJ. Sudden whitening of the hair: an historical fiction? J R Soc Med 2008;101:574-576.

7. Chan-Lam D, Fitzsimons EJ, Douglas WS. Alopecia after immunoglobulin infusion. Lancet 1987;1:1436. 


\title{
Neurology \\ Neuroimmunology \& Neuroinflammation
}

\author{
Overnight loss of pigmented hair in autoimmune autonomic neuropathy treated with \\ IVIg \\ Lindsey E. Turner, Sean J. Pittock, Marian T. McEvoy, et al. \\ Neurol Neuroimmunol Neuroinflamm 2019;6; \\ DOI 10.1212/NXI.0000000000000620
}

This information is current as of September 25, 2019

\section{Updated Information \& \\ Services}

References

Citations

Permissions \& Licensing

Reprints including high resolution figures, can be found at:

http://nn.neurology.org/content/6/6/e620.full.html

This article cites 7 articles, 1 of which you can access for free at: http://nn.neurology.org/content/6/6/e620.full.html\#\#ref-list-1

This article has been cited by 1 HighWire-hosted articles: http://nn.neurology.org/content/6/6/e620.full.html\#\#otherarticles

Information about reproducing this article in parts (figures,tables) or in its entirety can be found online at:

http://nn.neurology.org/misc/about.xhtml\#permissions

Information about ordering reprints can be found online: http://nn.neurology.org/misc/addir.xhtml\#reprintsus

Neurol Neuroimmunol Neuroinflamm is an official journal of the American Academy of Neurology.

Published since April 2014, it is an open-access, online-only, continuous publication journal. Copyright

Copyright (C) 2019 The Author(s). Published by Wolters Kluwer Health, Inc. on behalf of the American

Academy of Neurology.. All rights reserved. Online ISSN: 2332-7812.

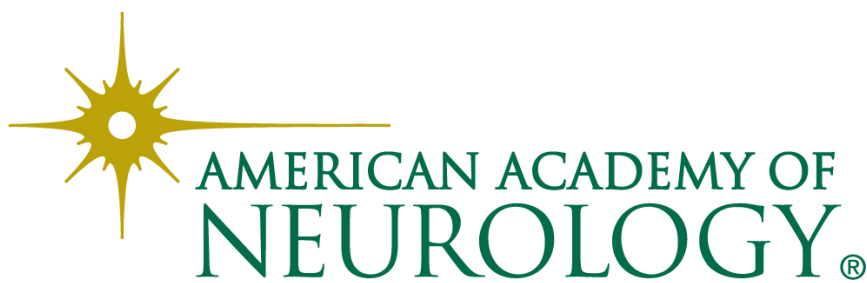

